Polyion complex templated synthesis of cross-linked single enzyme nanoparticles

\author{
Yiping Wang, ${ }^{a}$ Yen Theng Cheng, ${ }^{a, b}$ Cheng Cao, ${ }^{a}$ James D. Oliver, ${ }^{c}$ Martina H. Stenzel, ${ }^{a}$ and Robert
} Chapman ${ }^{*} a, b$

SUPPORTING INFORMATION

1. SYNTHETIC PROTOCOLS

2

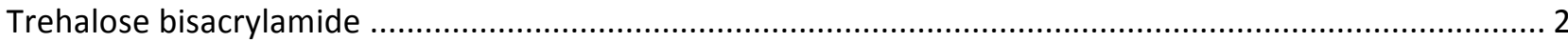

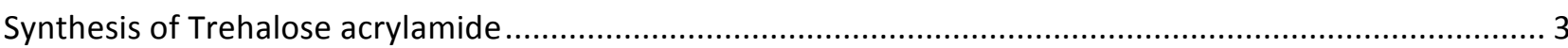

In Situ Polymerisation to make single enzyme nanogels without PIC templating .................................. 4

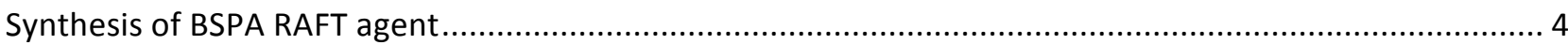

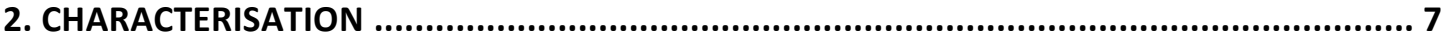

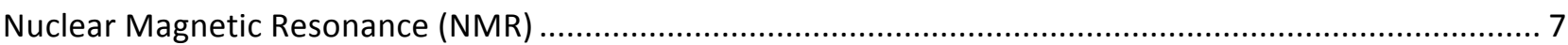

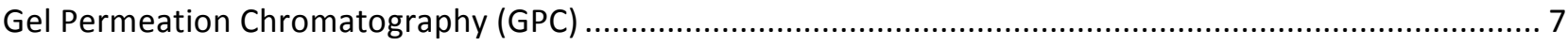

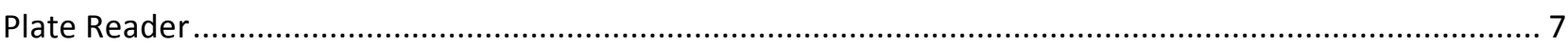

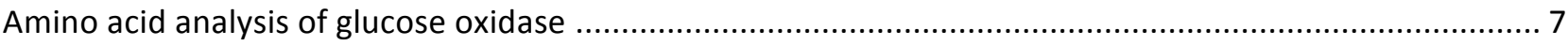

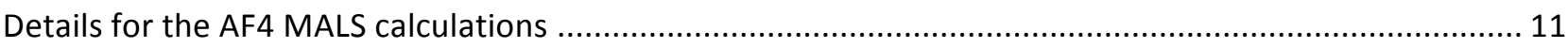

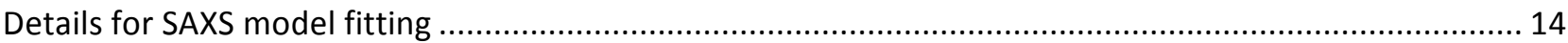




\section{SYNTHETIC PROTOCOLS}

\section{Trehalose bisacrylamide}

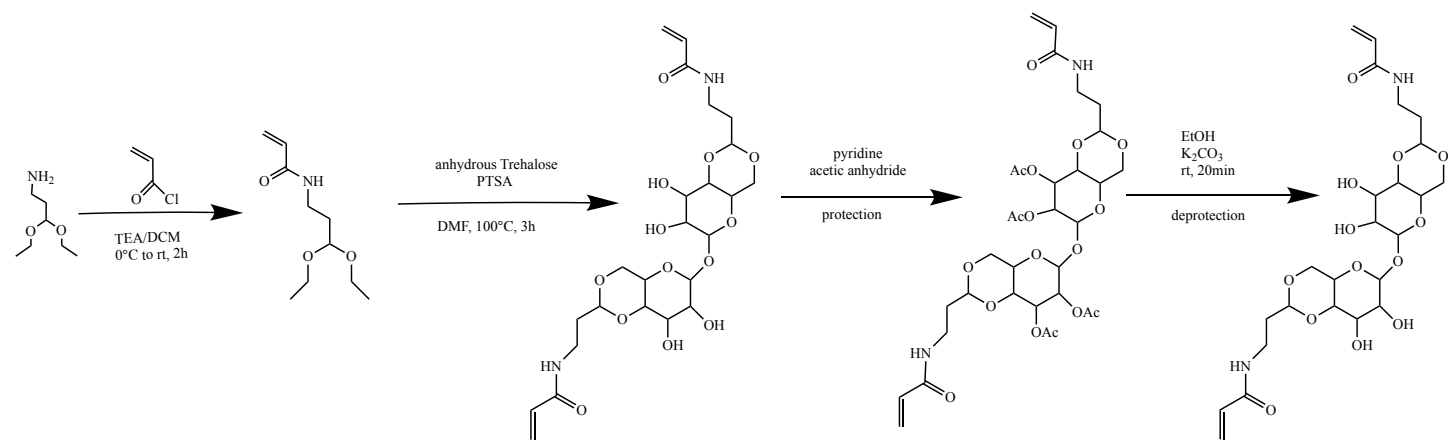

4,6-O-(di-3-propyl acrylamide)- $\alpha, \alpha$-trehalose was successfully synthesised in a two-step preparation pathway in moderate yield. $\mathrm{N}$-(3,3-diethoxypropyl)acrylamide was synthesised by dropwise addition of acryloyl chloride $(1350 \mathrm{mg}, 22.5 \mathrm{mmol})$ to a solution of 1-amino-3,3-diethoxypropane $(2205 \mathrm{mg}, 15 \mathrm{mmol})$ and triethylamine $(6120 \mathrm{mg}, 22.5 \mathrm{mmol})$ in dichloromethane $\left(\mathrm{CH}_{2} \mathrm{Cl}_{2}\right)$ at $0{ }^{\circ} \mathrm{C}$. The reaction was left to stir overnight before washing with water $(2 \times 50 \mathrm{~mL}), \mathrm{HCl}(0.1 \mathrm{M}, 2 \times 50 \mathrm{~mL})$ and brine $(1 \times 50 \mathrm{~mL})$. The organic layer was subsequently dried over anhydrous $\mathrm{MgSO}_{4}$ and concentrated by rotary evaporation. The product was purified by column chromatography (100\% EtOAc) and isolated to afford diethoxyacrylamide as yellow oil. (934mg, $4.65 \mathrm{mmol}$, yield: 31\%).

Anhydrous trehalose was prepared by heating D-(+)-trehalose dihydrate $\left(378 \mathrm{mg}, 1 \mathrm{mmol}\right.$ ) to $150{ }^{\circ} \mathrm{C}$ under vacuum until molten, which was later dissolved in $50 \mathrm{~mL}$ anhydrous dimethylformamide (DMF) at $100^{\circ} \mathrm{C}$ under nitrogen atmosphere. $p$-Toluenesulfonic acid (PTSA) (38 mg, $0.2 \mathrm{mmol}$ ) and hydroquinone (11 $\mathrm{mg}, 0.1$ $\mathrm{mmol})$ in anhydrous DMF $(1 \mathrm{~mL})$ were added into the solution. After stirring for $10 \mathrm{~min}$, the diethoxyacrylamide synthesised in the previous step $(603 \mathrm{mg}, 3 \mathrm{mmol}$ ) was added to the solution in a dropwise manner. After $3 \mathrm{~h}$, the reaction was quenched by removing DMF through vacuum evaporation. Because of the hydrophilicity of trehalose bisacrylamide, the free hydroxyl groups in the crude product were first protected by acetic anhydride in pyridine before it was purified by column chromatography over silica taking ethyl acetate: methanol (90: 10) as the eluent. Acetyl-deprotection was conducted by dissolving the product into the mixture of ethanol $(50 \mathrm{~mL})$ and overdose $\mathrm{K}_{2} \mathrm{CO}_{3}(12 \mathrm{mmol})$. After stirring for $20 \mathrm{~min}$, the mixture was filtered and dried to yield the trehalose-bisacrylamide monomer as a white powder $(184 \mathrm{mg}$, $0.29 \mathrm{mmol}$, yield: $29 \%$ ). The successful synthesis of trehalose cross-linker was verified by ${ }^{1} \mathrm{H}$ NMR (Figure S1). ${ }^{1} \mathrm{H}$ NMR (400 MHz, DMSO-d6): $\delta 8.10(\mathrm{t}, J=80.4 \mathrm{~Hz}, 2 \mathrm{H}, \mathrm{NH}), 6.23(\mathrm{dd}, J=22.0,28.8 \mathrm{~Hz}, 2 \mathrm{H}, \mathrm{CH}$ ), 6.09 (dd, $J=$ 22, $24.8 \mathrm{~Hz}, 2 \mathrm{H}, \mathrm{CH}$ ), 5.59 (dd, J = 16.8, 17.2 Hz, 2H, CH), 4.85 (d, J = 33.9 Hz, 2H, OCH), 4.60 (t, J = 47.2 Hz, $2 \mathrm{H}$, $\mathrm{OCH}), 3.97(\mathrm{~m}, 4 \mathrm{H}, \mathrm{OCH}), 3.678(\mathrm{t}, J=36.0 \mathrm{~Hz}, 2 \mathrm{H}, \mathrm{CH}), 3.52-3.10\left(\mathrm{~m}, 1 \mathrm{OH}, \mathrm{OCH}, \mathrm{OCH}_{2}, \mathrm{NH}_{2}, \mathrm{OCH}\right), 1.73(\mathrm{~m}$, $\left.4 \mathrm{H}, \mathrm{CH}_{2}\right)$. 


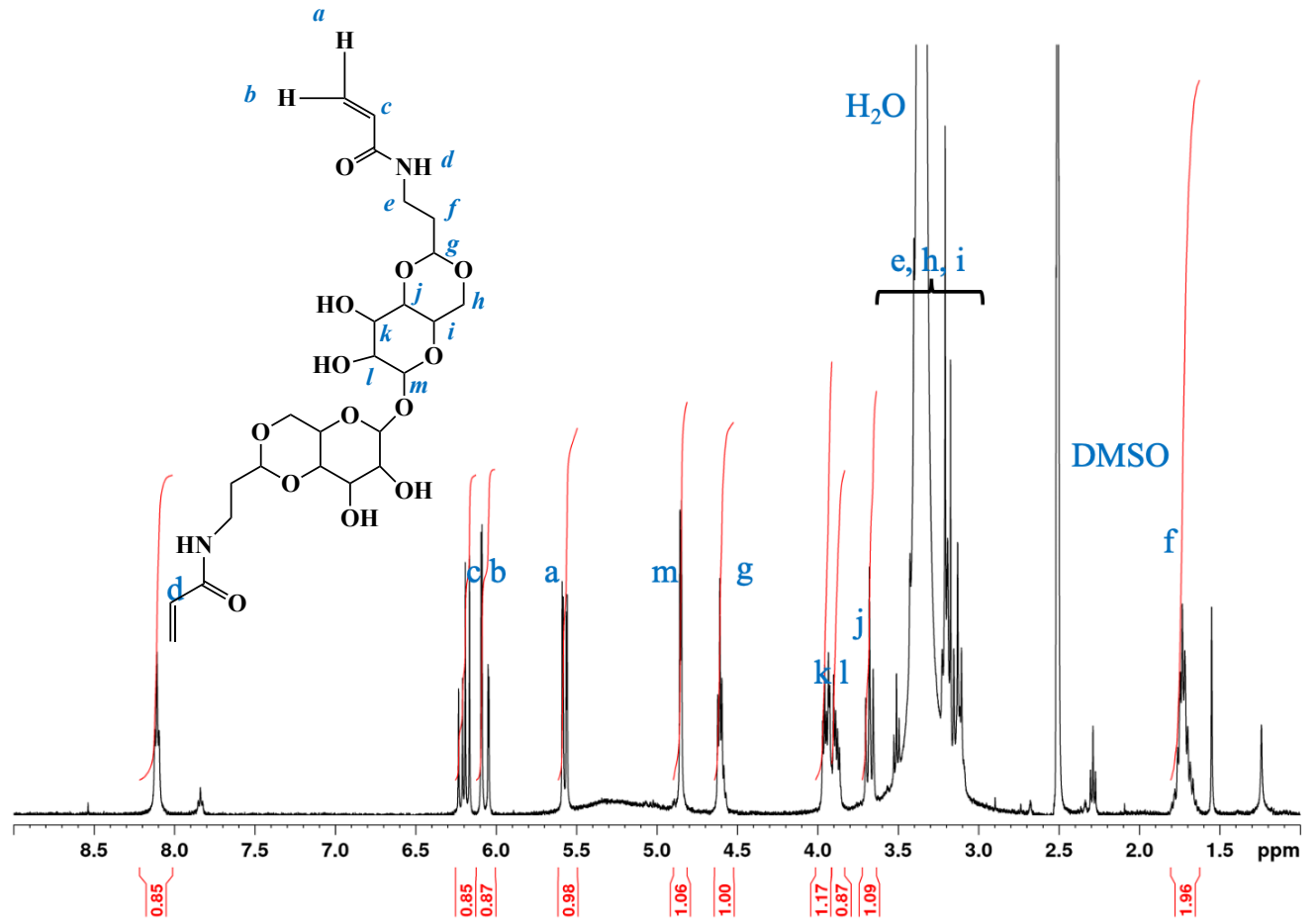

Figure S1 ${ }^{1} \mathrm{H}$ NMR of 4,6-O-(di-3-propyl acrylamide)- $\alpha, \alpha$-trehalose

\section{Synthesis of Trehalose acrylamide}

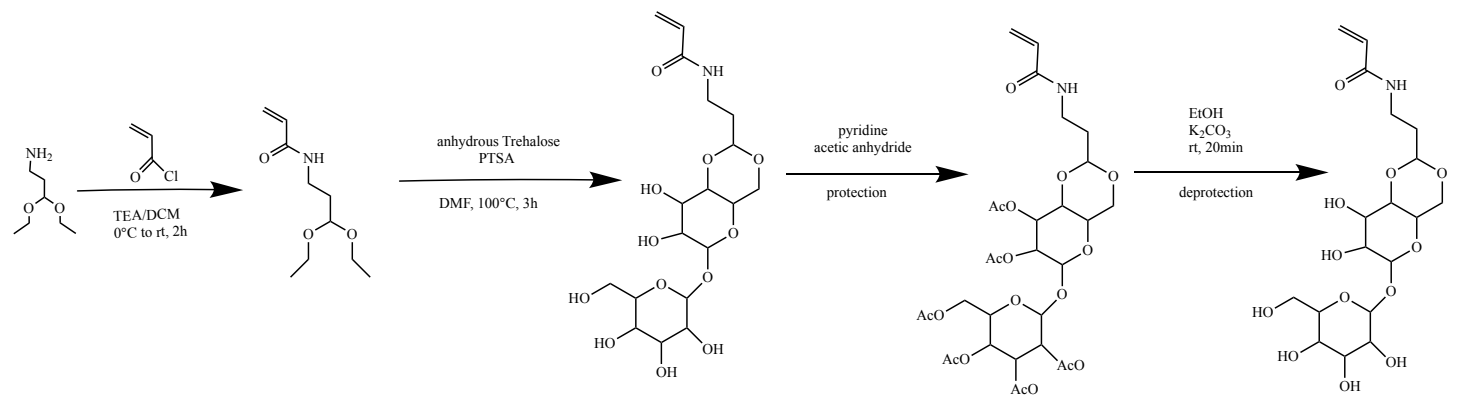

4,6-0-(3-propyl acrylamide)- $\alpha$, $\alpha$-trehalose was prepared in a similar way to that of 4,6-0-(3-propyl acrylamide)- $\alpha, \alpha$-trehalose. Overdose of D-(+)-trehalose dihydrate (1700 mg, $4.5 \mathrm{mmol}$ ), PTSA (114 mg, 0.6 $\mathrm{mmol}$ ) and hydroquinone $(33 \mathrm{mg}, 0.3 \mathrm{mmol}$ ) were used and the trehalose acrylamide monomer was yielded as a white powder (468 $\mathrm{mg}, 1.04 \mathrm{mmol}$, yield: 35\%). The successful synthesis of trehalose acrylamide was verified by the ${ }^{1} \mathrm{H}^{13} \mathrm{C}$ HSQC NMR (Figure S2). ${ }^{1} \mathrm{H}$ NMR (400 MHz, DMSO-d6): $\delta 8.15(\mathrm{t}, J=5.6 \mathrm{~Hz}, 1 \mathrm{H}, \mathrm{NH}), 6.21$ (dd, $J=17.1,10.1 \mathrm{~Hz}, 1 \mathrm{H}, \mathrm{CH}$ ), 6.07 (dd, $J=17.1,2.3 \mathrm{~Hz}, 1 \mathrm{H}, \mathrm{CH}$ ), 5.57 (dd, $J=10.1,2.3 \mathrm{~Hz}, 1 \mathrm{H}, \mathrm{CH}$ ), $4.91-4.79$ $(\mathrm{d}, 2 \mathrm{H}, \mathrm{CH}), 4.60(\mathrm{t}, J=5.1 \mathrm{~Hz}, 1 \mathrm{H}, \mathrm{OCH}), 3.95(\mathrm{dd}, J=9.8,4.9 \mathrm{~Hz}, 1 \mathrm{H}, \mathrm{OCH}), 3.86(\mathrm{td}, J=9.9,4.9 \mathrm{~Hz}, 1 \mathrm{H}, \mathrm{OCH})$, 3.75 - $3.64(\mathrm{~m}, 2 \mathrm{H}, \mathrm{OCH}, \mathrm{NH}), 3.27-3.06\left(\mathrm{~m}, 7 \mathrm{H}, \mathrm{OCH}_{2}, \mathrm{OCH}_{3}\right), 1.74\left(\mathrm{t}, J=7.8,7.0,3.8 \mathrm{~Hz}, 2 \mathrm{H}, \mathrm{CH}_{2}\right) ;{ }^{13} \mathrm{C} \mathrm{NMR}$ (101 MHz, DMSO-d6): $\delta 165.02(\mathrm{CO}), 132.27(\mathrm{CH}), 125.37(\mathrm{CH}), 100.32,94.57$ (d, J = 43.2 Hz, CH), $81.63(\mathrm{CH})$, $73.15(\mathrm{CH}), 72.72(\mathrm{CH}), 71.97(\mathrm{CH}), 70.52(\mathrm{CH}), 69.79(\mathrm{CH}), 68.36(\mathrm{CH}), 62.90(\mathrm{CH}), 61.17\left(\mathrm{CH}_{2}\right), 49.05\left(\mathrm{CH}_{2}\right)$, $34.83\left(\mathrm{CH}_{2}\right), 34.24\left(\mathrm{CH}_{2}\right)$. 


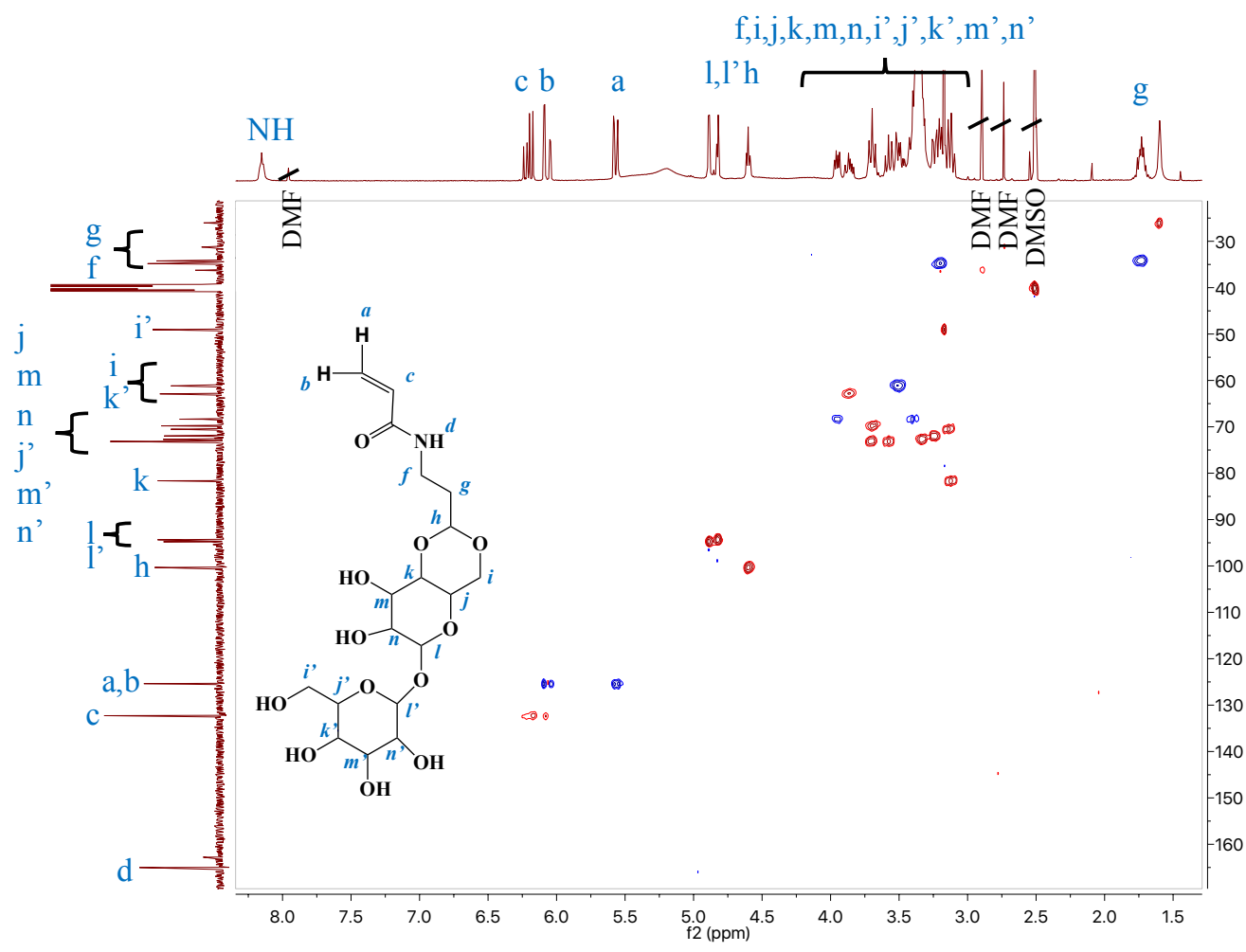

Figure S2 ${ }^{1} \mathrm{H}^{13}{ }^{13}$ HSQC NMR of 4,6-O-(3-propyl acrylamide)- $\alpha, \alpha$-trehalose.

\section{In Situ Polymerisation to make single enzyme nanogels without PIC templating}

GOx (4 mg) was first dissolved in PBS (1 mL) and degassed by bubbling $\mathrm{N}_{2}$ for $30 \mathrm{~min}$. Acrylamide and trehalose bisacrylamide (TMBAAm) in deoxygenated PBS and $N, N^{\prime}$-methylenebisacrylamide (MBAAm) in deoxygenated DMSO were subsequently added to the enzyme solution with different ratios. After stirring for $10 \mathrm{~min}$, ammonium persulfate (APS) and tetramethylethylenediamine (TEMED) in deoxygenated PBS were added to the mixture. The acrylamide/GOx, APS/GOx and TEMED/GOx ratios were kept constant at 12000, 1000 and 2000 respectively, while the TMBAAm/GOx and MBAAm/GOx ratio were changed from 0 to 2000 . Finally, the solution was adjusted to $2 \mathrm{~mL}$ to give a GOx concentration of $2 \mathrm{mg} / \mathrm{mL}$. The reaction was kept under $\mathrm{N}_{2}$ and shaken at room temperature for $4 \mathrm{~h}$. SENs were filtered by $0.22 \mu \mathrm{m}$ filter to remove high-molar mass aggregates.

\section{Synthesis of BSPA RAFT agent}<smiles>O=C(O)CC[Sn]</smiles>

3-(Benzylsulfanylthiocarbonylsulfanyl)-propionic acid (BSPA) was synthesised by following a previously reported method.[1] 1-Mercapto propionic acid was added $(2.12 \mathrm{~g}, 20 \mathrm{mmol})$ to $\mathrm{K}_{3} \mathrm{PO}_{4}(4.24 \mathrm{~g}, 20 \mathrm{mmol})$ in

${ }^{1}$ Skey, J.; O’Reilly, R. K. Facile One Pot Synthesis of a Range of Reversible Addition-Fragmentation Chain Transfer (RAFT) Agents. Chem. Commun. 2008, No. 35, 4183-4185. https://doi.org/10.1039/b804260h. 
acetone $(40 \mathrm{~mL})$, followed by stirring for $10 \mathrm{~min} . \mathrm{CS}_{2}(4.56 \mathrm{~g}, 60 \mathrm{mmol})$ was added to the solution. After 10 min, benzyl bromide $(3.40 \mathrm{~g}, 20 \mathrm{mmol})$ was added. The solvent was removed after $15 \mathrm{~min}$ under reduced pressure and the crude was added to a saturated solution of brine $(200 \mathrm{~mL})$ and extracted with $\mathrm{CH}_{2} \mathrm{Cl}_{2}(2 \mathrm{x}$ $200 \mathrm{~mL}$ ) and washed with saturated brine solution $(3 \times 200 \mathrm{~mL})$. After drying the organic extracts over anhydrous $\mathrm{MgSO}_{4}$, the solvent was removed under vacuum to give a yellow solid $(5.4 \mathrm{~g}, 20 \mathrm{mmol}$, yield > 99\%). ${ }^{1} \mathrm{H}$ NMR (400 MHz, $\left.\mathrm{CDCl}_{3}\right) \delta$ ppm: 7.29-7.39 (m, 5H, Ph), $4.63\left(\mathrm{~s}, J=54.7 \mathrm{~Hz}, 2 \mathrm{H}, \mathrm{CH}_{2}-\mathrm{Ph}\right), 3.64(\mathrm{t}, J=$ $\left.65.2 \mathrm{~Hz}, 2 \mathrm{H}, \mathrm{S}-\mathrm{CH}_{2}-\mathrm{CH}_{2}\right), 2.87\left(\mathrm{t}, J=72.0 \mathrm{~Hz}, 2 \mathrm{H}, \mathrm{S}-\mathrm{CH}_{2}-\mathrm{CH}_{2}\right.$ ) (Figure S3).

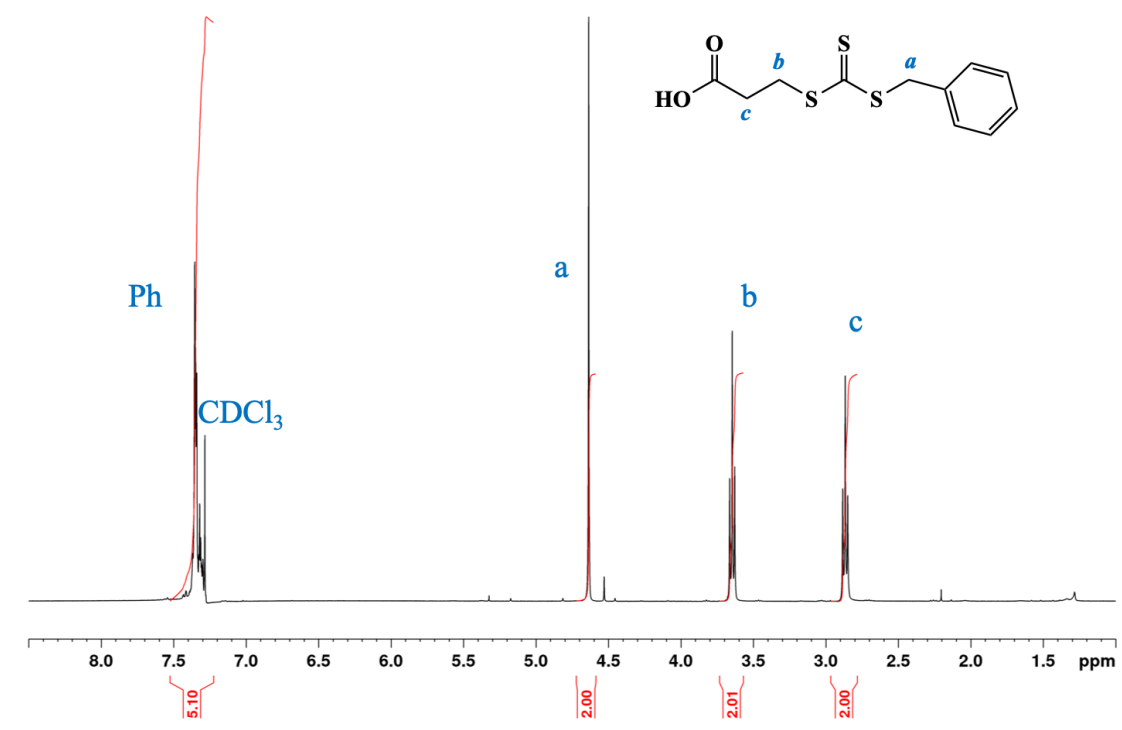

Figure S3. ${ }^{1}$ H NMR of 3-(benzylsulfanylthiocarbonylsulfanyl)-propionic acid (BSPA).

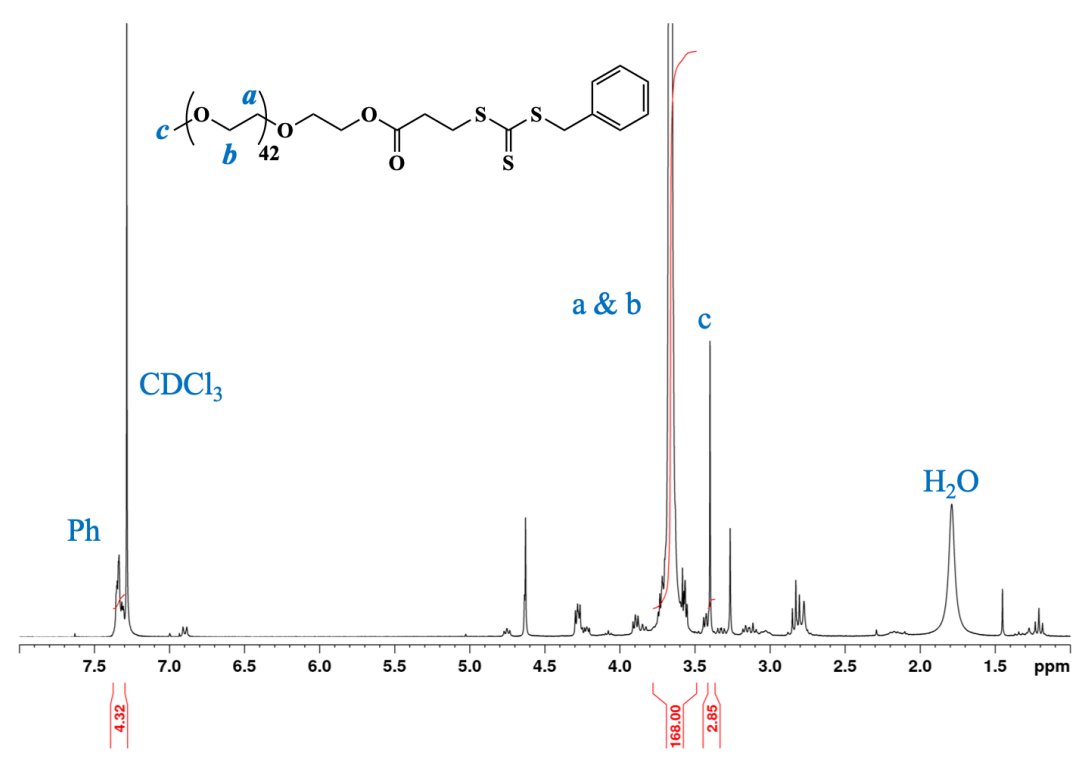

Figure S4 ${ }^{1} \mathrm{H}$ NMR of poly(ethylene glycol) 43 methyl ether 3-(benzylsulfanylthiocarbonylsulfanyl)-propionate ( $\left.\mathrm{PEG}_{43}-\mathrm{BSPA}\right)$. 


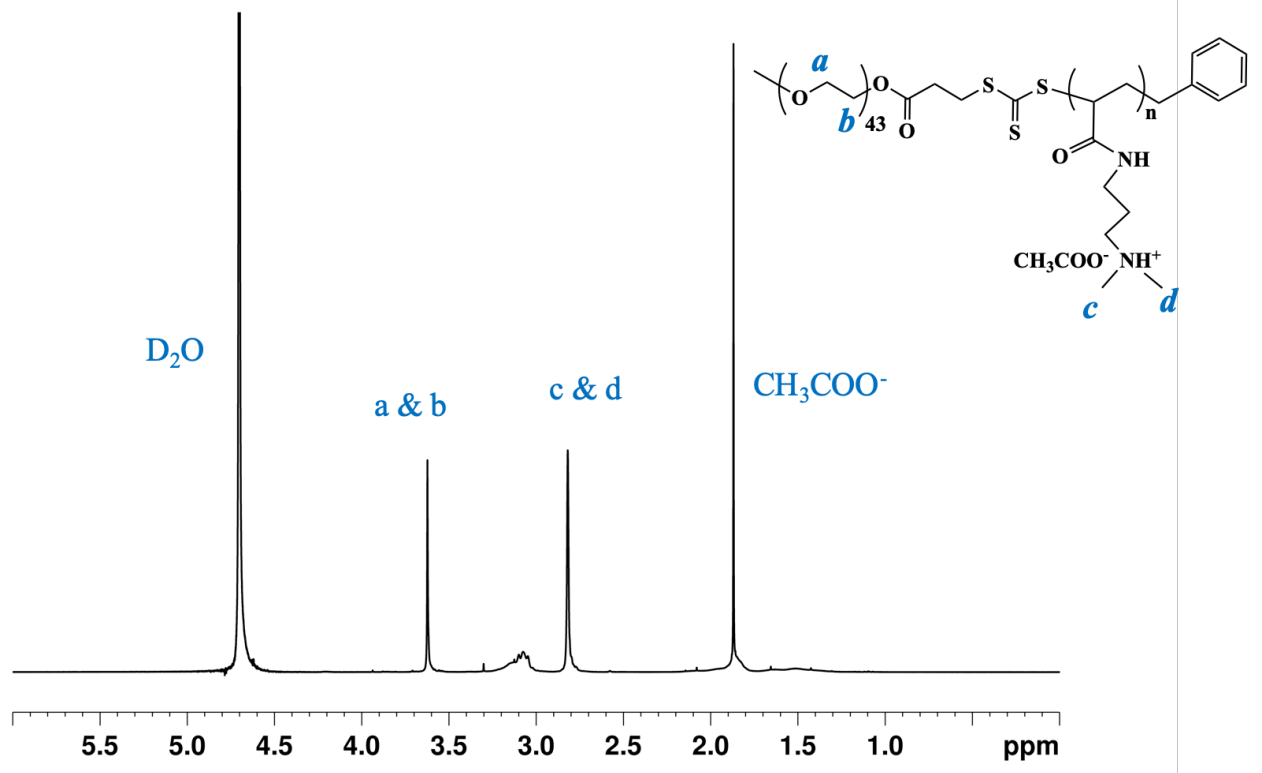

Figure S5 ${ }^{1} \mathrm{H}$ NMR of poly(ethylene glycol) ${ }_{43}$-b-poly(N-[3-(dimethylamino)propyl]acrylamide).

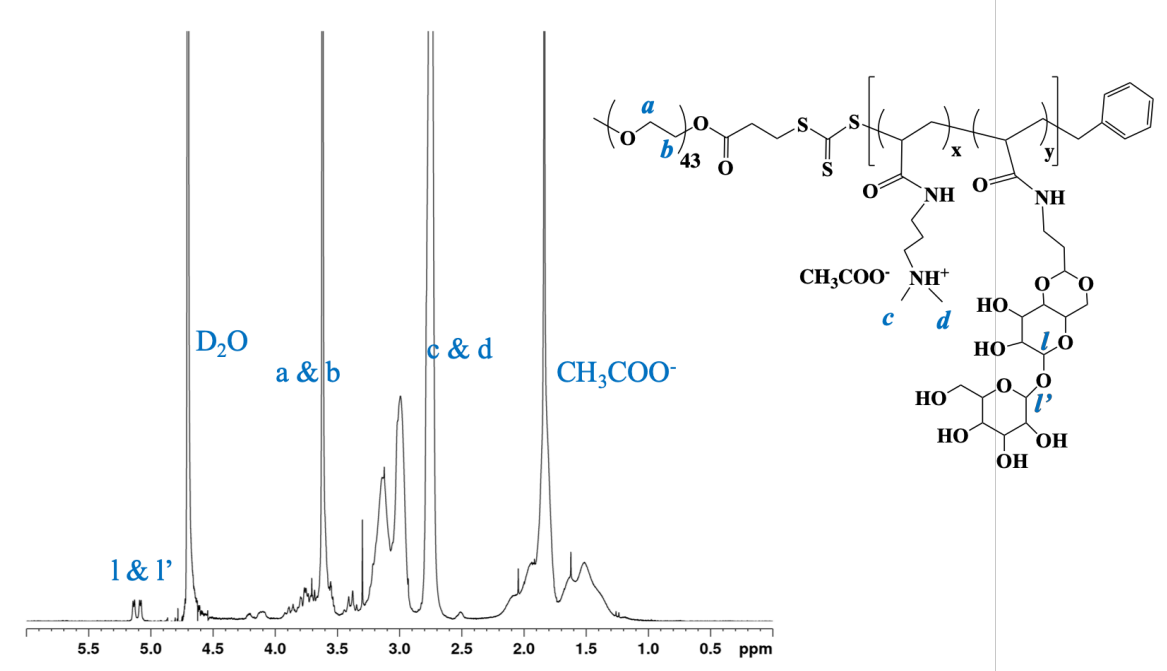

Figure S6 ${ }^{1} \mathrm{H}$ NMR of poly(ethylene glycol) $)_{43}-b$-poly (N-[3-(dimethylamino)propyl]acrylamide)-co-trehalose acrylamide). 


\section{CHARACTERISATION}

\section{Nuclear Magnetic Resonance (NMR)}

${ }^{1} \mathrm{H}$ NMR spectra were collected by using Bruker Advance III $400 \mathrm{MHz}$ NMR instruments, with a SampleXpress autosampler. Chemical shifts are reported in ppm $(\delta)$ relative to $\mathrm{CDCl} 3(7.26 \mathrm{ppm})$ or $\mathrm{D} 20(4.79 \mathrm{ppm})$ as internal reference.

\section{Gel Permeation Chromatography (GPC)}

GPC data for all polymers were obtained by a Shimadzu modular system containing a degasser (DGU-12A), a pump (LC-10AT) an automatic injector (SIL-10AD), a column oven (CTO-10A) and a refractive index detector (RID-10A). A 50×7.8 mm guard column and four $300 \times 7.8 \mathrm{~mm}$ linear columns $(500,103,104,105 \AA$ pore size, 5 $\mu \mathrm{m}$ particle size) were used for separation. $\mathrm{N}$, $\mathrm{N}$-dimethylformamide (HPLC grade, $0.05 \% \mathrm{w} / \mathrm{v} \mathrm{BHT}, 0.03 \% \mathrm{w} / \mathrm{v}$ $\mathrm{LiBr}$ ) was used as the eluent at a flow rate of $1 \mathrm{~mL} / \mathrm{min}$. The injection volume was $50 \mu \mathrm{L}$. The unit was calibrated using polystyrene standards (0.5-1000 kDa, Polymer Laboratories).

\section{Plate Reader}

A plate reader equipped with a UV spectrophotometer (Tecan, Infinite M200) is employed at a wavelength of $450 \mathrm{~nm}$ for the enzyme activity measurements.

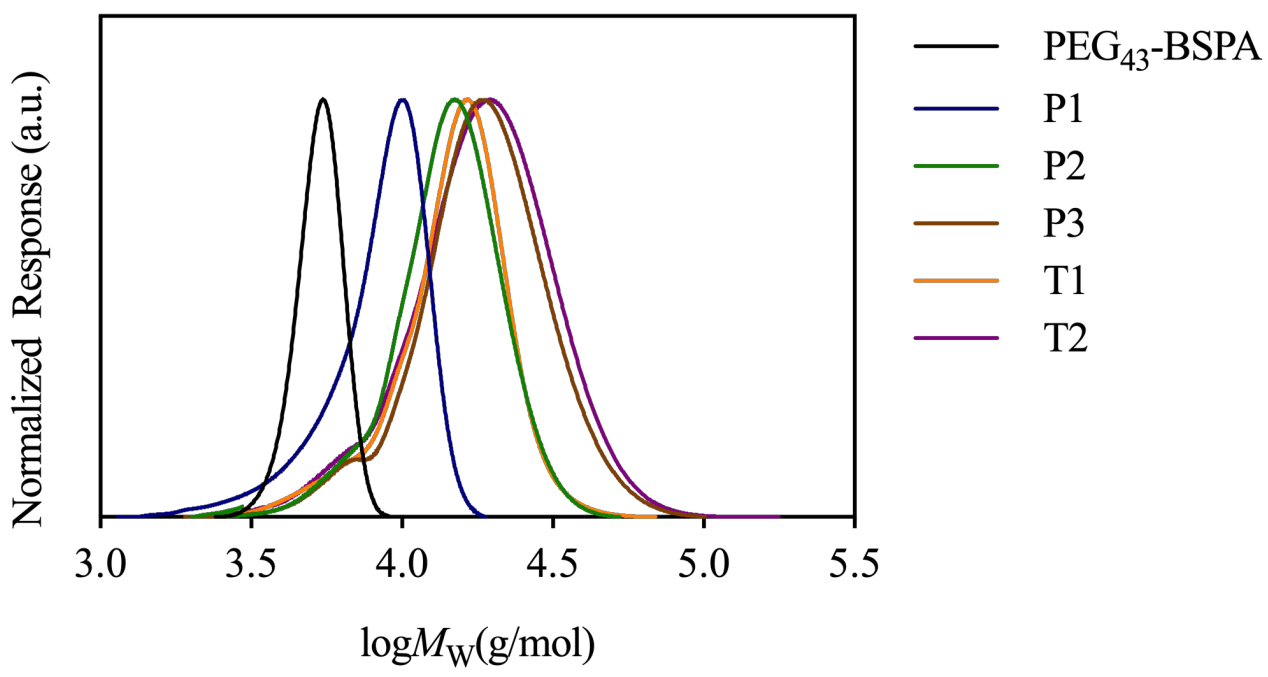

Figure S7 GPC results of different lengths of positively charged polymer.

\section{Amino acid analysis of glucose oxidase}

Sequence (RCSB 1GAL): MQTLLVSSLV VSLAAALPHY IRSNGIEASL LTDPKDVSGR TVDYIIAGGG LTGLTTAARL TENPNISVLV IESGSYESDR GPIIEDLNAY GDIFGSSVDH AYETVELATN NQTALIRSGN GLGGSTLVNG GTWTRPHKAQ VDSWETVFGN EGWNWDNVAA YSLQAERARA PNAKQIAAGH YFNASCHGVN GTVHAGPRDT GDDYSPIVKA LMSAVEDRGV PTKKDFGCGD PHGVSMFPNT LHEDQVRSDA AREWLLPNYQ RPNLQVLTGQ YVGKVLLSQN GTTPRAVGVE FGTHKGNTHN VYAKHEVLLA AGSAVSPTIL EYSGIGMKSI LEPLGIDTVV DLPVGLNLQD QTTATVRSRI TSAGAGQGQA AWFATFNETF GDYSEKAHEL LNTKLEQWAE EAVARGGFHN TTALLIQYEN 
YRDWIVNHNV AYSELFLDTA GVASFDVWDL LPFTRGYVHI LDKDPYLHHF AYDPQYFLNE LDLLGQAAAT QLARNISNSG AMQTYFAGET IPGDNLAYDA DLSAWTEYIP YHFRPNYHGV GTCSMMPKEM GGVVDNAARV YGVQGLRVID GSIPPTQMSS HVMTVFYAMA LKISDAILED YASMQ

Table S1. Amino acid analysis of glucose oxidase (taken from RCSB:1GAL)

\begin{tabular}{|c|c|c|c|}
\hline Residue type & Amino acids & $\begin{array}{c}\text { \# Residues in } \\
\text { sequence }\end{array}$ & Total \\
\hline \multirow{3}{*}{ Positive } & $\mathrm{K}$ & 15 & \multirow{3}{*}{58} \\
\hline & $\mathrm{H}$ & 20 & \\
\hline & $\mathrm{R}$ & 23 & \\
\hline \multirow{2}{*}{ Negative } & $D$ & 36 & \multirow{2}{*}{66} \\
\hline & $E$ & 30 & \\
\hline \multirow{4}{*}{ Polar uncharged } & $S$ & 40 & \multirow{4}{*}{139} \\
\hline & $\mathrm{T}$ & 43 & \\
\hline & $\mathrm{N}$ & 33 & \\
\hline & Q & 23 & \\
\hline \multirow{4}{*}{ Special } & $\mathrm{C}$ & 3 & \multirow{4}{*}{86} \\
\hline & $U$ & 0 & \\
\hline & G & 57 & \\
\hline & $P$ & 26 & \\
\hline \multirow{8}{*}{ Hydrophobic } & $A$ & 61 & \multirow{8}{*}{256} \\
\hline & V & 46 & \\
\hline & I & 27 & \\
\hline & L & 54 & \\
\hline & $M$ & 12 & \\
\hline & $\mathrm{F}$ & 18 & \\
\hline & $\mathrm{Y}$ & 28 & \\
\hline & W & 10 & \\
\hline
\end{tabular}



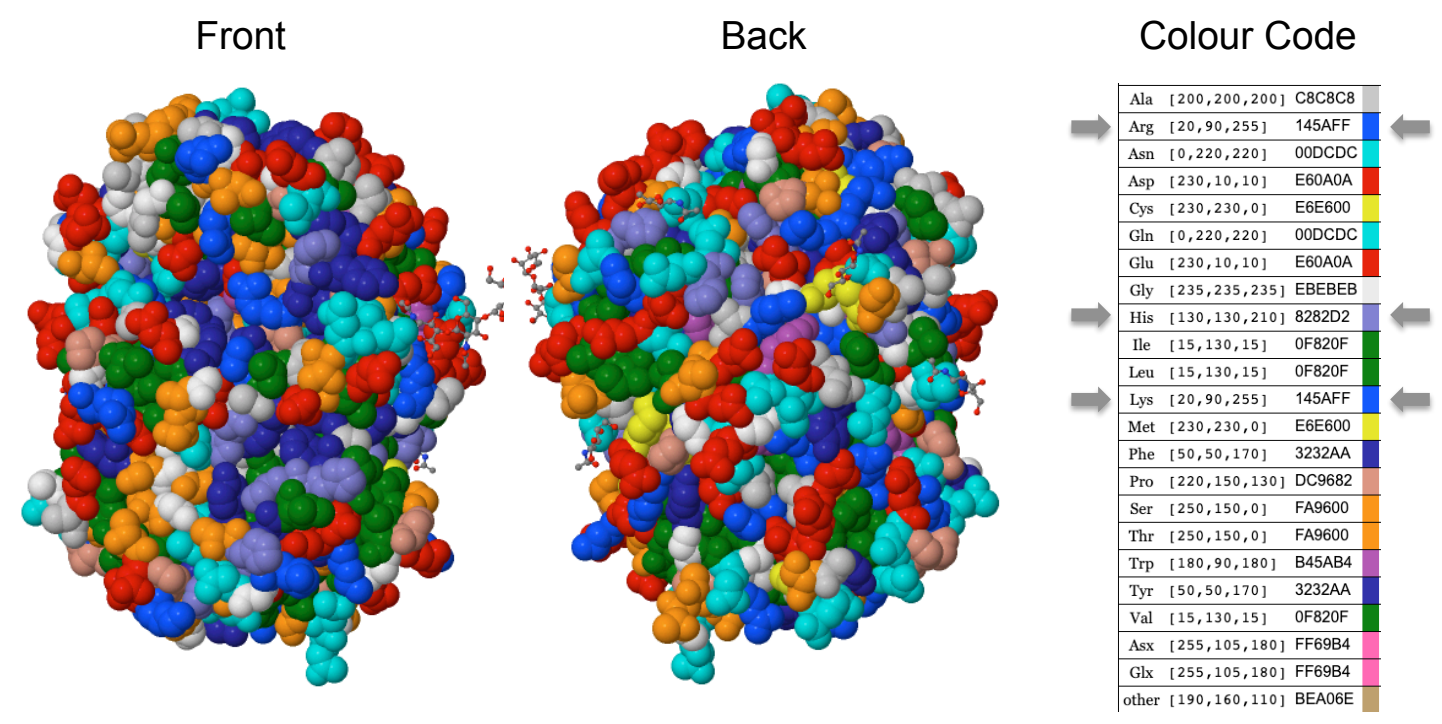

Figure S8. Amino acid analysis of glucose oxidase taken from RCSB:1GAL, coloured by amino acids. The positive residues are highlighted.

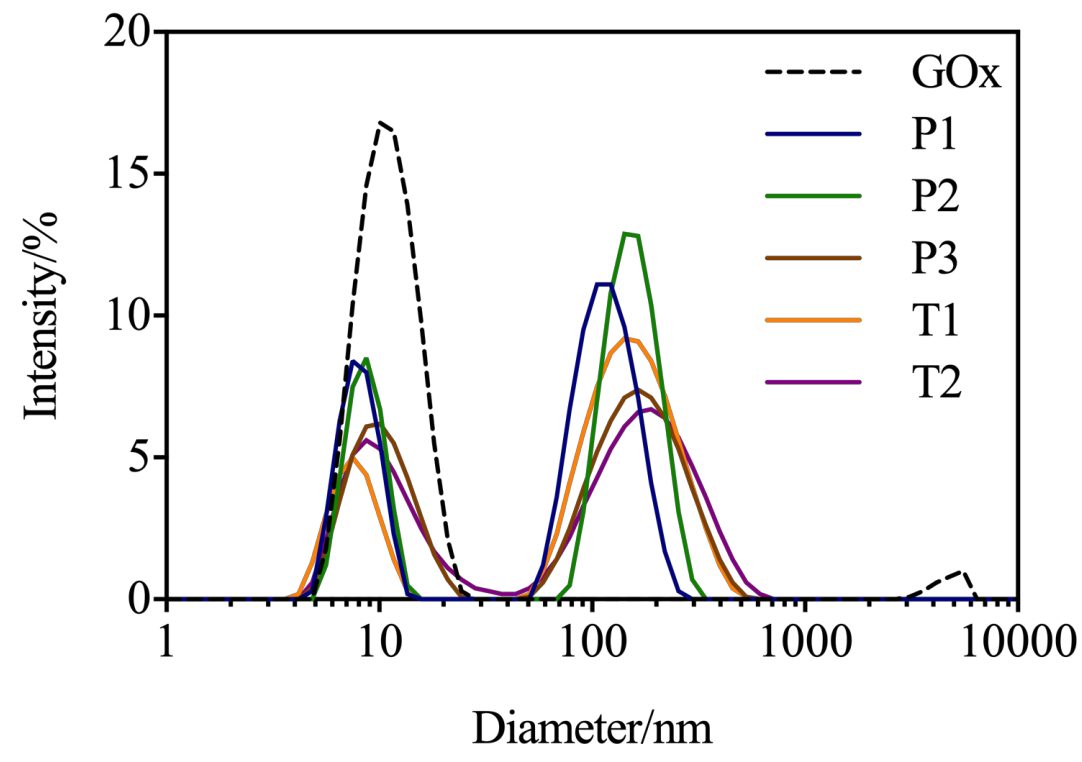

Figure S9. Dynamic light scattering (DLS) data for polymer alone at same concentration as SENs with 30 polymer/ GOx. 

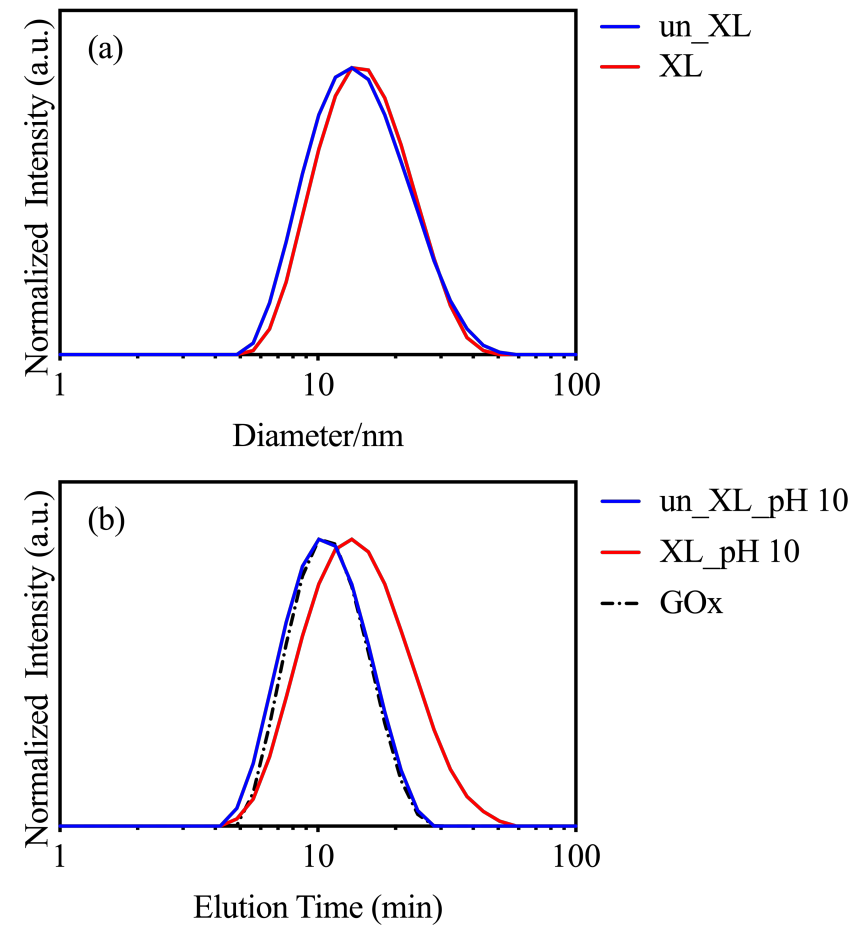

(c)
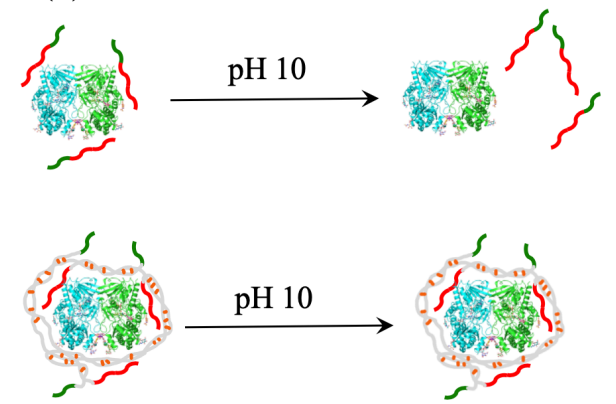

Figure S10. DLS results of uncross-linked (un_XL) and cross-linked (XL) P2-R10 (a) before and (b) after base treatment; (c) the illustration for the effect of alkali treatment on the uncross-linked and cross-linked SENs. 


\section{Details for the AF4 MALS calculations}

The determination of protein fraction and $\mathrm{Mw}$ values from AF4/UV-Vis/RI/MALS also required the specific refractive index increments $(d n / d c)$ and UV extinction coefficient $(\varepsilon)$ of the samples, which were determined as follows: the $\varepsilon$ value of GOx at $280 \mathrm{~nm}$ is known, which is $1.67 \mathrm{~mL} / \mathrm{g} \mathrm{cm}$. The $d n / d c$ value of the protein was determined from the RI detector response with the exact protein injected mass and it is $0.163 \mathrm{~mL} / \mathrm{g}$. The $d n / d c$ and $\varepsilon$ of polymers in PBS was measured by injection of a series of known concentrations of polymers $(0.2,0.40 .60 .8$ and $1 \mathrm{mg} / \mathrm{mL})$ directly into the RI and UV detector without the connection of the AF4 channel and they are summarized in Table S1.

The protein fraction of SENs can be calculated through the combination of on-line UV-Vis and RI. While the two components in SEN contribute to the UV and RI signal differently, the mass concentration of SEN calculated from the RI signal ( $\left.C_{d R I}\right)$ and the UV signal ( $\left.C_{U V}\right)$ is same, which is eq. (1). Specifically, $C_{d R I}$ is given by $C_{d R I}=\frac{\Delta n}{(d n / d c)_{S E N}}$, where $\Delta n$ is the change in refractive index as measured by the RI detector; $C_{\mathrm{UV}}$ is given by $C_{U V}=\frac{A b s}{\varepsilon_{S E N} \cdot L}$, where Abs is the absorption as measured by the UV detector and $L$ is the path length. Combined these with eq. (1), we can get eq. (2). $(d n / d c)_{S E N}$ and $\varepsilon_{S E N}$ can be approximated as the weight average of the $d n / d c$ and $\varepsilon$ of the two individual components, and then we can calculate GOx fraction in SENs (x) from eq (3).

$C_{d R I}=C_{U V}$

$\frac{\Delta n}{\left(\frac{d n}{d c}\right)_{S E N}}=\frac{A b s}{\varepsilon_{S E N} \cdot L}$

$\frac{\Delta n}{(d n / d c)_{G O X} \cdot x+(d n / d c)_{\text {Polymer }} \cdot(1-x)}=\frac{A b s / L}{\varepsilon_{G O X} \cdot x+\varepsilon_{\text {polymer }} \cdot(1-x)}$

Once the $\mathrm{x}$ is calculated, then $(d n / d c)_{S E N}$ could be calculated by:

$(d n / d c)_{S E N}=(d n / d c)_{G O x} \cdot x+(d n / d c)_{P o l y m e r} \cdot(1-x)$

The total molar mass of the SEN (M) is related to the measured intensity of the MALS signal (I) as follows:

$M_{S E N} \propto \frac{I}{(d n / d c)_{S E N}^{2} \cdot C_{S E N}}$ 
Table S2. The refractive index increments and UV extinction coefficient of polymers of GOx and polymers in PBS used in the AF-MALS analysis.

\begin{tabular}{lcccccc}
\hline & GOx & P1 & P2 & P3 & T1 & T2 \\
\hline $\boldsymbol{d n} / \boldsymbol{d} \boldsymbol{c}(\mathrm{mL} / \mathrm{g})$ & 0.163 & 0.168 & 0.155 & 0.162 & 0.164 & 0.161 \\
$\boldsymbol{\varepsilon}(\mathrm{mL} / \mathrm{g} \mathrm{cm})$ & 1.67 & 0.156 & 0.126 & 0.083 & 0.108 & 0.095 \\
\hline
\end{tabular}

Table S3. Results of protein fraction calculation by both methods, and Mn as calculated by AF4 for the PIC micelles before cross-linking for P1-3 at saturation (20 eq. polymer for P1, 10 eq. polymer for P2, and 5 eq. polymer for P3.

\begin{tabular}{lccc}
\hline & P1-R20 & P2-R10 & P3-R5 \\
\hline Protein fraction obtained from AF4/MALS/UV-Vis/RI (\%) & 75.4 & 71.6 & 81.3 \\
Protein fraction obtained from ITC \& NMR (\%) & 77.25 & 77.66 & 71.99 \\
Mn (kDa) & 175.2 & 176.5 & 190.9 \\
\hline
\end{tabular}
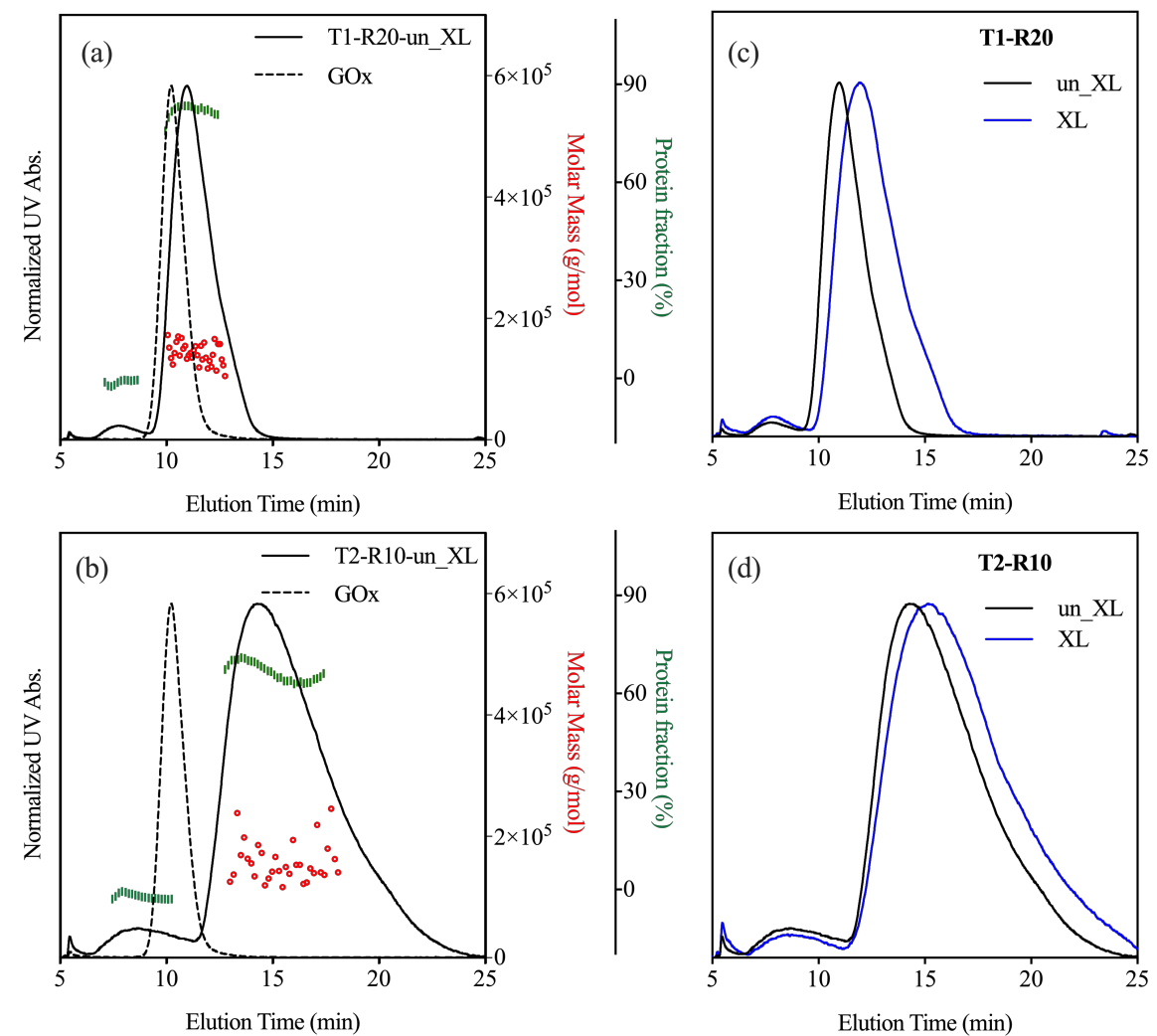

Figure S11. AF4/UV-Vis traces, protein fraction (in green) and the molecular weight (in red) of assembled SENs produced from a) T1, b) T2 with 20 and 10 polymer/GOx ratio respectively. c) and d) show the AF4/UV-Vis traces for the same SENs before and after the crosslinking reaction with acrylamide and methylene bisacrylamide. 


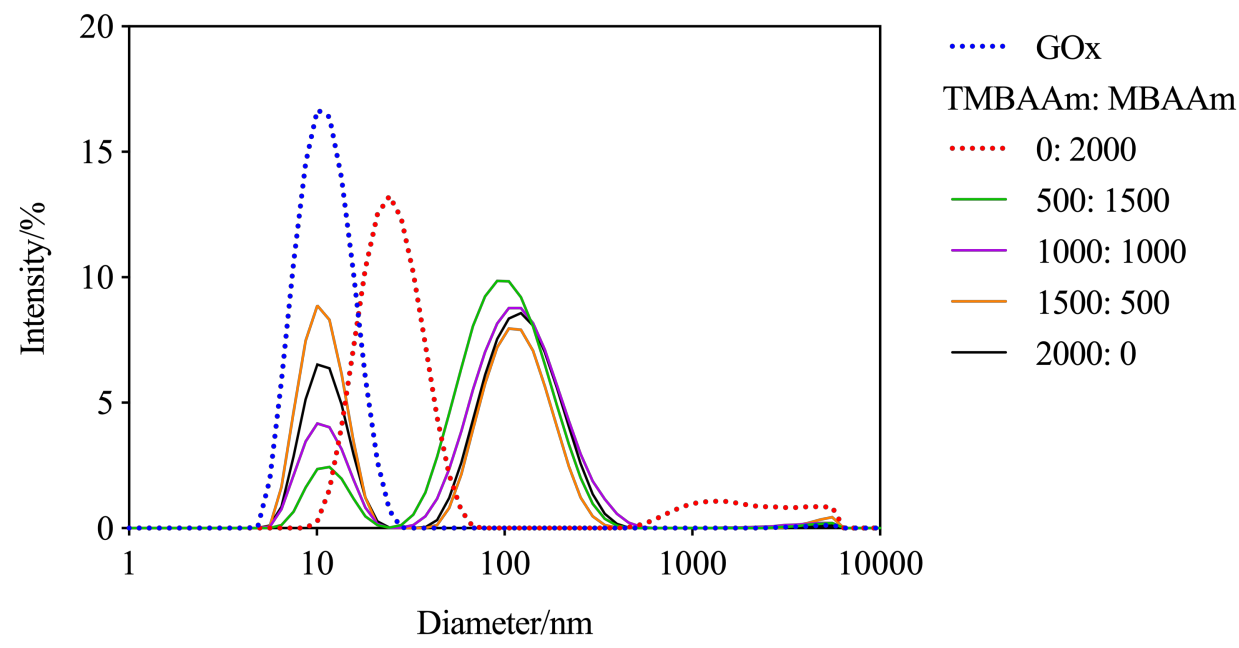

Figure S12. DLS size distributions by intensity of the particles made by in situ polymerisation with different ratio of TMBAAm/MBAAm/GOx. 


\section{Details for SAXS model fitting}

The form functions, and the final fitting parameters for the two models used were taken from the NIST NCR IgorPro package [2].

a) Guinier-porod model: The dimension variable ' $s$ ' was set to 0 , in all cases as this results in the form function for globular objects.

$I(Q)=\frac{G}{Q^{s}} \exp \left[\frac{-Q^{2} R_{g}{ }^{2}}{3-s}\right]$ for $Q \leq Q_{1}$

$I(Q)=\frac{D}{Q^{m}}$ for $Q \geq Q_{1}$

where:

$Q_{1}=\frac{1}{R_{g}} \sqrt{\frac{(m-s)(3-s)}{2}}$

$D=G \exp \left[\frac{-Q_{1}^{2} R_{g}^{2}}{3-s}\right] Q_{1}^{(m-s)}=\frac{G}{R_{g}^{(m-s)}} \exp \left[-\frac{(m-s)}{2}\right]\left(\frac{(m-s)(3-s)}{2}\right)^{\frac{(m-s)}{2}}$

Table S4. Final Guinier-porod fitting parameters for the GOx and crosslinked SENS for the fits shown in Figure 5. Parameters which were held constant are highlighted in blue.

\begin{tabular}{lccccc}
\hline & Native GOx & $\begin{array}{c}\text { P1-GOx } \\
\text { (crosslinked) }\end{array}$ & $\begin{array}{c}\text { P2-GOx } \\
\text { (crosslinked) }\end{array}$ & $\begin{array}{c}\text { P3-GOx } \\
\text { (crosslinked) }\end{array}$ & $\begin{array}{c}\text { T2-GOx } \\
\text { (crosslinked) }\end{array}$ \\
\hline Guinier Scale & 18.7 & 27.6 & 30.2 & 31.8 & 36.5 \\
Dimension Variable, s & 0 & 0 & 0 & 0 & 0 \\
Rg (Å) & 37.6 & 40 & 43 & 44 & 42 \\
Porod Exponent & 4.5 & 3.6 & 3.3 & 3.5 & 2.7 \\
Bgd $\left(\mathrm{cm}^{-1}\right.$ ) & 0 & 0 & 0 & 0 & 0 \\
\hline
\end{tabular}

${ }^{2}$ https://www.nist.gov/ncnr/data-reduction-analysis/sans-software 
b) Fuzzy spheres model: This model was taken from Stiener et al. [3] and used as supplied in the NIST NCR IgorPro macros.

$$
I(q)=\frac{\text { scale }}{V}(\Delta \rho)^{2}\left\langle A^{2}(q)\right\rangle S(q)+\frac{I_{l o r}(0)}{1+\xi^{2} q^{2}}+b k g
$$

where the amplitude $A(q)$ is given as the typical sphere scattering convoluted with a Gaussian to get a gradual drop-off in the scattering length density:

$A(q)=\frac{3[\sin (q R)-q R \cos (q r)]}{(q R)^{3}} \exp \left\{\frac{-\left(\sigma_{\text {surf }} q\right)^{2}}{2}\right\}$

The Lorentzian term accounts for the fluctuations arising from the microgel network, with $\mathrm{x}$ being the correlation length of the fluctuations, which is related to the blob or mesh size in the network. The radius in the second row was set to the radius of native glucose oxidase (as determined from the fit from the GP model), as this represents the core of the SEN in this model. We held this constant in order to model the effect of the polymer shell as the "fuzzy sphere" around this core. The starting SLD for the core of the sphere was estimated using a scattering length density calculator and the molecular formula for glucose oxidase $\left(\mathrm{C}_{2917} \mathrm{H}_{4373} \mathrm{~N}_{795} \mathrm{O}_{848} \mathrm{~S}_{15}\right)$ but was adjusted in the native GOx sample to achieve the best fit and then held constant across all other fits so that the only variation introduced was from the interface.

Table S5. Final fuzzy spheres fitting parameters for the GOx and crosslinked SENS for the fits shown in Figure 5. Parameters which were held constant are highlighted in blue.

\begin{tabular}{llllll}
\hline & Native GOx & $\begin{array}{l}\text { P1-GOx } \\
\text { (crosslinked) }\end{array}$ & $\begin{array}{l}\text { P2-GOx } \\
\text { (crosslinked) }\end{array}$ & $\begin{array}{l}\text { P3-GOx } \\
\text { (crosslinked) }\end{array}$ & $\begin{array}{l}\text { T2-GOx } \\
\text { (crosslinked) }\end{array}$ \\
\hline Volume Fraction (scale) & 0.60 & 0.78 & 0.99 & 0.79 & 0.64 \\
Mean radius ( $(\AA)$ & 37.6 & 37.6 & 37.6 & 37.6 & 37.6 \\
Polydisp (sig/avg) & 0.2 & 0.2 & 0.2 & 0.2 & 0.2 \\
Interface thickness ( $(\AA)$ & $\mathbf{2 . 0}$ & $\mathbf{9 . 8}$ & $\mathbf{1 3 . 7}$ & $\mathbf{1 1 . 5}$ & $\mathbf{7 . 0}$ \\
SLD sphere $\left(\AA^{-2}\right)$ & $1.04 \times 10^{-5}$ & $1.04 \times 10^{-5}$ & $1.04 \times 10^{-5}$ & $1.04 \times 10^{-5}$ & $1.04 \times 10^{-5}$ \\
SLD solvent $\left(\AA^{-2}\right)$ & $9.50 \times 10^{-6}$ & $9.50 \times 10^{-6}$ & $9.50 \times 10^{-6}$ & $9.50 \times 10^{-6}$ & $9.50 \times 10^{-6}$ \\
Lorentz Scale & 4.2 & 9.7 & 5.5 & 25.2 & 35.8 \\
Lorentz length $(\AA)$ & 57.0 & 43.6 & 36.0 & 78.5 & 58.0 \\
bkg $\left(\mathrm{cm}^{-1} \mathrm{sr}^{-1}\right.$ ) & 0 & 0 & 0 & 0 & 0 \\
\hline
\end{tabular}

${ }^{3}$ M. Stieger, J. S. Pedersen, P. Lindner, W. Richtering, Langmuir 20 (2004) 7283-7292. 